\title{
The Use of GIS and Remote Sensing to Investigate Groundwater Vulnerability to Contamination and Surface Water Susceptibility to Pollution at Mafraq Dumpsite/Jordan
}

\author{
Rida Al-Adamat
}

\begin{abstract}
This study will evaluate how vulnerable groundwater is to contamination in Jordan, whilst further determining how prone to pollution surface water is. Situated upon what is believed to be one of Jordan's most important groundwater aquifers, the Mafraq dumpsite is understood to be a great hazard to the quality of water. With the ability to thoroughly assess both groundwater and surface water, the DRASTIC and SWSi indexes have been utilized throughout this study, providing further insight into whether the Mafraq dumpsite is located in a location where groundwater and surface water are vulnerable to contamination. The results gathered stress that the dumpsite is indeed located in an area where groundwater is at moderate risk of becoming contaminated. Additionally, surface water is at high risk of becoming contaminated due to the proximity of the dumpsite to the drainage system (Wadis) in the area. In conclusion, as the aquifer is used for both drinking and irrigation purposes, it is likely that human health is in jeopardy. Furthermore, it is apparent that the quality of both groundwater and surface water might be compromised as a result of the dumpsite.
\end{abstract}

Index Terms-Groundwater, surface water, GIS, Mafraq, dumpsite.

\section{INTRODUCTION}

As a result of being within the semi-arid climate zone location, rainfall in Jordan is limited, impacting the amount of renewable water available. In addition to the Jordan location, a rise in population [1] resource misallocation and tension with bordering nations dividing the same resources have intensified the issue at hand. According to [2] only $30 \%$ of Jordan's water resources arise as groundwater. As with many other countries, groundwater resources across Jordan are imperative for the economic wellbeing and population of residents. Therefore it is vital to control the condition and volume of the water in a sustainable manner if conceivable contaminations are to be prevented. However, according to [3] there are numerous factors that compromise the quality of groundwater, including hazardous landfilling. [1] stated that over the last fifty years, Jordan has witnessed an upsurge in population. Whilst this growth is said to have positively impacted living conditions, whilst transforming consumer traditions, it has also resulted in an escalation of waste volume. Material gathered by [4] emphasizes that Jordan's production of solid waste in the community is estimated to be

Manuscript received August 12, 2018; revised October 14, 2018.

Rida Al-Adamat is with Department of GIS and Remote Sensing, Institute of Earth and Environmental Sciences, Al al-Bayt University, Mafraq, Jordan (e-mail: ridaali@aabu.edu.jo).
1.96 million tons per year, with an average generation rate of $0.95 \mathrm{~kg} / \mathrm{cap} /$ day in urban and $0.85 \mathrm{~kg} / \mathrm{cap} /$ day in rural areas. However, by 2015 it was expected that this figure would reach 2.5 million tons. In Jordan the most common form of landfilling is via trenches. This method of disposal consists of waste being dumped in trenches, prior to being leveled, compacted and covered in soil [5] in order to reduce the size of landfills. Whilst [6] believes that landfilling is the most straightforward method for disposing of waste, it is critical that it is pursued thoroughly to ensure that the trenches do not compromise the quality of groundwater. Based on [7]-[9], landfills will continue to pose as a threat to groundwater quality. On the other hand, about $28 \%$ total water supplied to residents in Jordan is made up of surface water from rivers including the Jordan, the Yarmouk and the Zarqa. These rivers together supply $239 \mathrm{MCM} /$ year of water to the country, with the Jordan river providing $50 \mathrm{MCM} /$ per year alone. [10] believes that leachate spawned from landfill sites has the ability to compromise the quality of surface water in Wadis and dams.

This study will adopt a novel approach of using two indices to examine the groundwater vulnerability to contamination and surface water susceptibility to pollution for the area surrounding the Mafraq dumpsite. Both indices will be implanted using GIS analysis capabilities.

\section{Methods}

\section{A. Study Area}

In order to ensure that in-depth and accurate research can be conducted, this research will cover an area of $110.58 \mathrm{~km}^{2}$ surrounding the Mafraq dumpsite. Located approximately 10 km East of Mafraq city (see Fig. 1), the Mafraq dumpsite sits is $5 \mathrm{~km}$ from the main highway and $0.5 \mathrm{~km}$ from the nearest community in the area. The dumpsite being investigated is situated within the Amman-Zarqa groundwater basin, which is considered the most important groundwater basin in the country. The basin is utilized for drinking and irrigation purposes, the location of the dumpsite poses as a threat to the quality of the water, thus further jeopardizing residents health. The dumpsite receives more than 130 tons of waste per day from domestic and agriculture sources ([11], [12]). [11] stated that the dumpsite obtains a large quantity of municipal, industrial and medical waste from Mafraq city, Za'atari refugee camp and villages in the vicinity, which has the capability to develop groundwater pollution. The author goes on to confirm that often the waste can prove to be difficult to 
process and manage due to high loading. Gaining an understanding of how waste is disposed of on the dumpsite highlights that after being disposed of, a team of up to thirty employees categorize the waste into plastic, cardboard and paper, metallic waste and aluminum waste. All remaining waste is then loaded onto transportation for conclusive deposition. According to [13] and [14] the Mafraq dumpsite is considered to be insanitary because it is not covered with soil and it can take up to twelve months before there is any natural soil covering. The dumpsite is located on the basaltic aquifer which means that leachate has the ability to enter groundwater. Furthermore, the dumpsite has no system for the treatment and/or recollection of leachate.

Fig. (2.a) shows that yearly precipitation in the areas being studied fluctuates between $100 \mathrm{~mm}$ in the East to $200 \mathrm{~mm}$ in the West. Furthermore, it can be seen that elevation varies between $627 \mathrm{~m}$ to $720 \mathrm{~m}$ above sea level, however an incline towards the South and South West can be noticed (Fig. 2.b). Through the winter periods, surface water is more prone to flow towards the Wadi, that directly streams towards the River Zarqa. It should also be noted that the area being studied consists of two geology classes; basalt and limestone (Fig. 2.c). The soil contributing to these classes include silt loam and silty clay loam, which has a clay percentage of between $20 \%$ and $30 \%$ (Fig. 2.d). Fig. (2.e) provides insight into how the land being studied is utilized. Whilst the majority of land is made up of farming land, a small percentage of the land is used for urban and waste purposes.

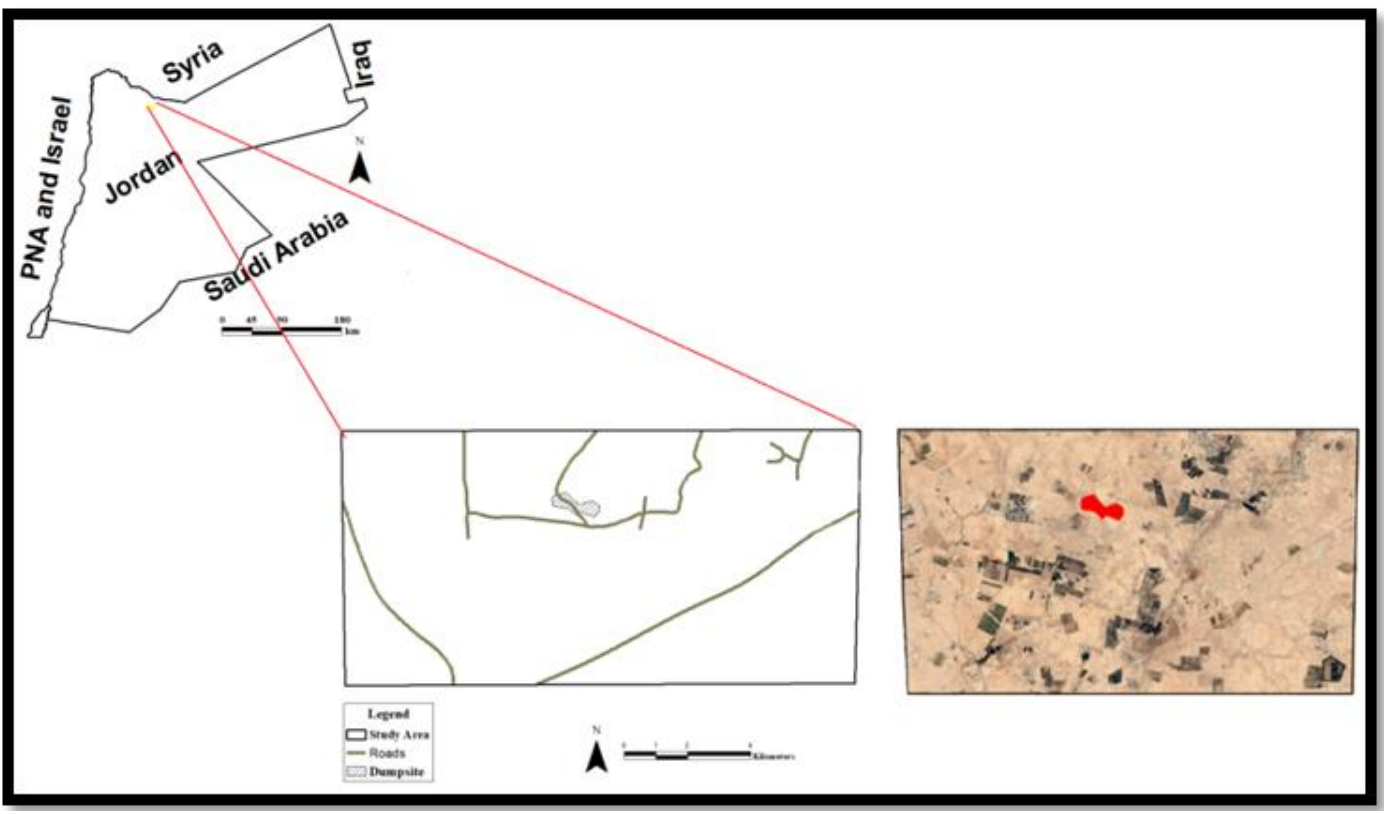

Fig. 1. Study area location.

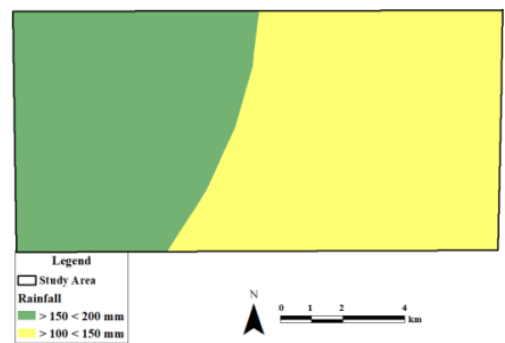

(a) Rainfall within the study area

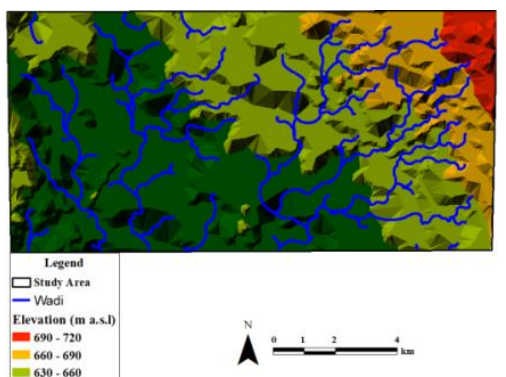

(b) Elevations and Wadis with the study area

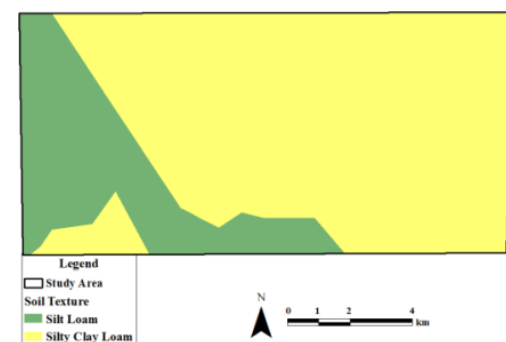

(c) Soil Texture for the study area

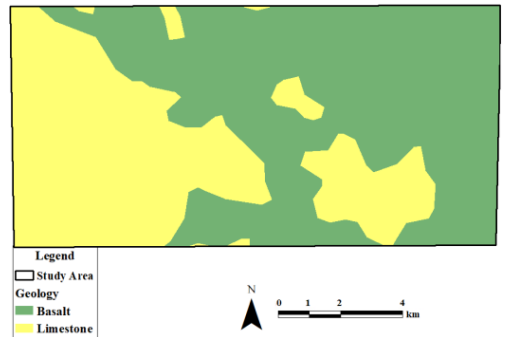

(d) The Geology of the study area

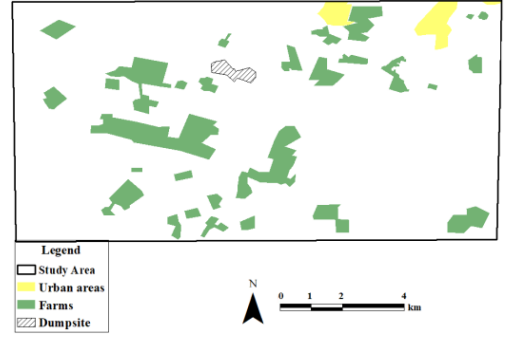

(e) Land uses within the study area

Fig. 2. Study area characteristics.

\section{B. Data Analysis Methods}

1) Groundwater vulnerability to contamination

Utilizing maps that demonstrate the vulnerability of 
groundwater to contamination is imperative in this specific field of research. Utilizing these tools enables planners to not only understand and address occurring problems in the groundwater, but also provides a deeper insight into pollutant movement in the soil. [15] believe that acquiring this information makes it feasible to reduce the potential harm to groundwater. With numerous methods including process-based mathematical methods, statistical methods, overlay and indexing methods available at hand, all ensure groundwater vulnerability can be assessed, it is crucial to consider which may be best to use in this instance. This study will focus specifically on overlay and index methods which rely on mathematical portrayals of professional opinions as opposed to experimental statistics. Whilst these factors have many benefits, it is known that utilizing numerical values can often be biased. There are many models of established overlay and index methods which include, but are not limited to; DRASTIC ([16]-[22]), GOD ([23]-[25]), EPIK ([26]-[28]), SINTACS ([29]-[31]), PI ([32]), COP ([22] and [28]) and SGVI ([33]).

Throughout this research project, the DRASTIC index will be employed to scrutinize wither groundwater vulnerable to contamination in the surrounding area of the dumpsite. Developed by the US Environmental Protection Agency, the DRASTIC model is an acronym for D: Depth to water table; R: net Recharge; A: Aquifer media; S: Soil media; T: Topography; I: Impact of the Vadose Zone and C: Hydraulic Conductivity of the aquifer.

Each of the letters within the DRASTIC model provides individual insight into different factors that must be considered within research. These can be seen below;

Depth to Water Table; Determines the depth that a contaminant must travel prior to reaching the groundwater.

Net Recharge; The net recharge focuses on the availability of water to transport contamination both vertically and horizontally. When transported vertically, water takes the contamination to the water table, however upon being transported horizontally, water takes the contamination to the aquifer. The net recharge also has the ability to control the availability of water for dispersion and dilution purposes.

Aquifer Media; Responsible for controlling the direction within the aquifer, the aquifer media ascertains the time offered for dilution processes to occur.

Soil; With a momentous power over the way in which recharge can penetrate the water table, soil has the ability to restrict contaminant movement. For example, if the area of soil appears to be dense, the process of filtration, biodegrading, sorption and volatilization is trivial. Additionally, if the soil contains fine-textured materials, contamination migration can be reduced.

Topography; With the ability to control pollutant retention on the surface whilst influencing the development of soil, topography is capable of reducing contamination.

Impact of Vadose Zone; The Impact of Vadose Zone determines the attenuation characteristics of soil and rock and controls the route and path length of attenuation.

The Hydraulic Conductivity; Controlling the rate at which groundwater flows, the hydraulic conductivity further determines the rate at which groundwater enters the aquifer.

The DRASTIC index (DI) is established by applying the following formula (Eq. 1):

$$
\begin{aligned}
\mathrm{DI}=\mathrm{Dr} \times \mathrm{Dw}+\mathrm{Rr} \times \mathrm{Rw}+\mathrm{Ar} \times \mathrm{Aw}+\mathrm{Sr} \times \mathrm{Sw}+\mathrm{Tr} \times \mathrm{Tw}+\mathrm{Ir} \times \mathrm{Iw} \\
+\mathrm{Cr} \times \mathrm{Cw}
\end{aligned}
$$

where $r$ : rating, $w$ : weight.

As noted in Table I, the DRASTIC index is categorized into four divisions that represent the vulnerability of groundwater. Within the index, the lowest class is seen to fall

\begin{tabular}{|c|c|c|c|}
\hline $\mathrm{TH}$ & HYDRAUL & CONDU & TIVITY) \\
\hline & RASTIC Q & alitative & Classes \\
\hline $\begin{array}{c}\text { Low } \\
20-65\end{array}$ & $\begin{array}{c}\text { Moderate } \\
65-110\end{array}$ & $\begin{array}{c}\text { High } \\
110-15 \\
5\end{array}$ & $\begin{array}{c}\text { Very High } \\
155-200\end{array}$ \\
\hline
\end{tabular}
at 20, whilst the highest class achieves a result of 200.

\section{2) Surface water susceptibility to pollution}

Crucial to enable pollution risk maps to be drawn, surface water and its susceptibility to pollution must be reviewed [34]. Secondary research highlights that there are numerous studies that enable surface waters susceptibility to pollution to be investigated ([34]-[41]). [35] stated that the available studies provide researchers with the ability to design models and estimate how susceptible surface water is to pollution.

In the above mentioned researches, slope, land use, land cover, distance to water sources and groundwater contribution were analyzed. These indexes were employed to estimate surface water susceptibility to pollution within GIS environments. Utilizing GIS enables sensitivity and pollution variables to be measured within the specified areas. Applying a methodology devised by [34] will enable the researcher to investigate surface water susceptibility to pollution within the study area. The methodology bases its findings on the SWSi pollution index which consists of six factors; gradient slope (GS) as a percentage, distance to Wadi (DW), soil clay (SC) as a percentage, distance to agricultural lands (DA), distance to urban areas (DU) and distance to roads (DR).

Surface water run off occurs when there is surplus water on a gradient slope (GS) because surface water cannot be absorbed into soil. Therefore, the steeper a slope, the more likely a runoff will arise [42]. [38] stated that surface water has the ability to become more susceptible to pollution when infiltration is low and runoff is high, therefore the distance to Wadi (DW) plays a crucial part in determining whether surface water is vulnerable. With numerous properties that could potentially lead to the movement of pollutants to farming land, high clay contents soils (SC), combined with degrading surface structures of soil, has the capability to restrict infiltration, leading to an increase in water runoff. With agricultural non-point source (NPS) pollution believed to be the leading source of pollution to surface water in rivers and lakes [43], it was considered essential to consider the distance to Agricultural lands (DA). The urban areas (DU) were considered essential to the study as the dumpsite poses as a significant threat to the quality of surface water in the area. Believed to be one of the most harmful factors affecting surface water health by [44] urban runoff is considered a challenge due to altering the metal and nutrient levels within the water. Furthermore, with the power to contaminate 
surface water, roads (DR) are branded a key source of pollution [45]. The SWSi is classified into four surface water susceptibility to pollution classes (Table II), the SWSi index is established by applying the following formula (Eq. 2):

$$
\begin{gathered}
\mathrm{SWSi}=\mathrm{GSw} \times \mathrm{GSr}+\mathrm{DSw} \times \mathrm{DSr}+\mathrm{SCw} \times \mathrm{SCr}+\mathrm{Daw} \times \mathrm{Dar}+ \\
\text { Duw } \times \mathrm{DUr}+\mathrm{DR} w \times \mathrm{DRr}
\end{gathered}
$$

where, $w$ : weight and $r$ : ratings.

TABLE II: SWSI QUALITATIVE CLASSES (BASED ON [34])

\begin{tabular}{c|c|c|c}
\hline \hline \multicolumn{4}{c}{ SWSi Qualitative Classes } \\
\hline Low & Moderate & High & Very High \\
$21-42$ & $42-63$ & $63-84$ & $84-105$ \\
\hline
\end{tabular}

\section{Data Collection}

Table III displays sets of data that have previously been collected by national and international agencies. These data contribute towards the final objectives and purpose of this research project.

TABLE III: The Data SETS USED IN THIS RESEARCH AND THEIR SOURCES

\begin{tabular}{lcc}
\hline \hline $\begin{array}{l}\text { Map } \\
\text { type }\end{array}$ & Scale & Source \\
\hline Geology & $1: 250,00$ & Natural Resources Authority of Jordan \\
& 0 & \\
Slope & $1: 250,00$ & \\
& 0 & Extracted from the Shuttle Radar Topography \\
Wadis & $1: 250,00$ & Mission (SRTM DEM), USGS \\
& 0 & \\
Soil & $1: 250,00$ & \\
& 0 & \\
Rainfall & $1: 250,00$ & \\
& 0 & \\
Land use & $1: 250,00$ & Extracted from Google Earth (GeoEye) images \\
& 0 & \\
\end{tabular}

It should be noted that the slope map has been extracted utilizing ArcGIS based on the Shuttle Radar Topography Mission (SRTM DEM). Furthermore, the SRTM DEM was employed to create the drainage system (Wadis) for the study area using flow accumulation function ArcGIS. Additionally, using Google Earth has ensured that a land use map can be generated based on the on the screen digitizing technique ([48], [49]).

\section{DATA ANALYSIS AND RESULTS}

\section{A. The DRASTIC Index}

Having collected data, Table IV reviews the DRASTIC parameters for the outlined study area. Information gathered emphasis that each parameter has a unique single value. As the depth of groundwater is typically more than $30.48 \mathrm{~m}$, the depth to groundwater (D) has a parameter of $w \times r$ of 5 for the entire study area. The net recharge I has $w \times r$ totaling 4 as rainfall within the area being studied is usually less than 200 $\mathrm{m}$ a year, generating a net recharge of less than $50.8 \mathrm{~mm}$ annually. Due to lack of available data, the hydraulic conductivity I has been eliminated from the DRASTIC calculation [20]. As demonstrated in Table IV, the A, S, T and I parameters have varying $\mathrm{w} \times \mathrm{r}$ values. These parameters were combined using the raster calculation in ArcGIS, which can be observed in Fig. (3), based on Eq. 1. Additionally, a pre-set total of 9 represents the sum of $w \times r$ for the $D$ and $R$ parameters. The results of this procedure has been classified based on Table I as outlined in Fig. (3).

TABLE IV: THE DRASTIC PARAMETERS FOR THE STUdy AREA (MODIFIED FROM [16] AND [20])

\begin{tabular}{lcccc}
\hline \hline DRASTIC Parameters & Class & $\begin{array}{c}\text { Weight } \\
(\mathbf{w})\end{array}$ & $\begin{array}{c}\text { Rating } \\
\text { I }\end{array}$ & $\begin{array}{c}\text { w× } \\
\text { r }\end{array}$ \\
\hline $\begin{array}{l}\text { Depth to water Range (m) } \\
\text { (D) }\end{array}$ & $>30.48$ & 5 & 1 & 5 \\
Net recharge Range & & & & \\
(mm/year) I & $0.0-50.8$ & 4 & 1 & 4 \\
Aquifer Media (A) & Limestone & 3 & 8 & 24 \\
& Basalt & & 9 & 27 \\
& Silty & & 4 & 8 \\
Soil Media (S) & Loam & 2 & & \\
& Clay & & 3 & 6 \\
& Loam & & 10 & 10 \\
Slope (\%) (T) & $0-2$ & 1 & 1 & 1 \\
& $>18$ & & 3 & 15 \\
Vadose Zone material (I) & Limestone & 5 & 9 & 45 \\
\hline \hline
\end{tabular}

Fig. (3) illustrates that the Mafraq dumpsite lies within an area where groundwater is exposed to contamination, thus compromising the quality of the groundwater in the area. A study conducted by [50] exhibited high levels of nitrate concentration within groundwater at the Amman-Zarqa basin. The levels of the nitrate varied from $10 \mathrm{mg} / \mathrm{l}$ to $330 \mathrm{mg} / \mathrm{l}$. Samples from the area indicated that more than $20 \mathrm{mg} / \mathrm{l}$ of concentration was present in the water, which the authors claimed to be an effect of uncontrolled landfilling practices in the Mafraq dumpsite. An additional study undertaken by [51] concluded that in addition to nitrate being present in the water, mercury was too. The samples of mercury found in wells situated near the dumpsite were as high as $0.17 \mathrm{mg} / \mathrm{l}$. As mercury concentrations in groundwater rarely exceed $0.0005 \mathrm{mg} / 1$ [52], an increase in concern to human wellbeing was noted. According the [52] such a high level of mercury concentration is deadly to human beings and can result in damage to the kidneys. However, it is believed that the appearance of mercury concentration was not a result of mineral weathering, but an outcome of anthropogenic nature, including batteries, barometers and thermometers. In addition to nitrate and mercury found in the groundwater, fluoride concentrations were noticed in wells. Fluoride concentrations found measured beyond the recommended guidelines of $1.5 \mathrm{mg} / \mathrm{l}$ and varied between $3.8 \mathrm{mg} / \mathrm{l}$ to 14.2 $\mathrm{mg} / \mathrm{l}$. At such a high level, it is almost guaranteed that there would be copious health related risks including dental and skeletal fluorosis.

\section{B. The SWSi Index}

Based on the collected data for the study area, Table (5) lists the SWSi parameters for the study area. This table lists only the ratings for the study area and for the detailed SWSi index see [33]. Fig. (3) shows the GS, DW, SC, DA, DU and DR parameters which were combined together (Eq. 2) using the raster calculation in ArcGIS. The outcome of this operation was then classified based on Table (2) as shown in Fig. (4).

Fig. (4) empathizes that the Mafraq dumpsite is positioned in an area where surface water is prone to pollution, 
signifying that the dumpsite compromises the quality of surface water throughout winter.

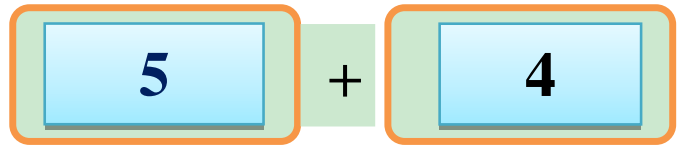

Depth to Groundwater

(D)
Net Recharge

(R)

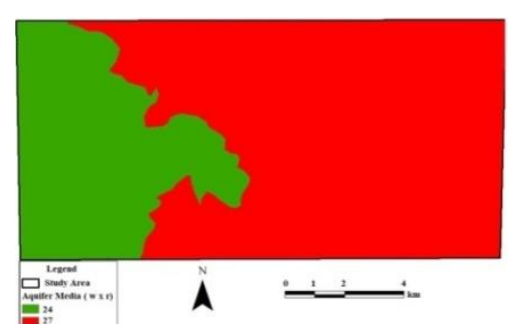

Aquifer Media (A)

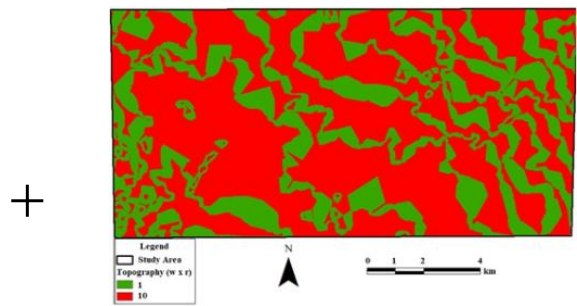

Topographic Slope (T)

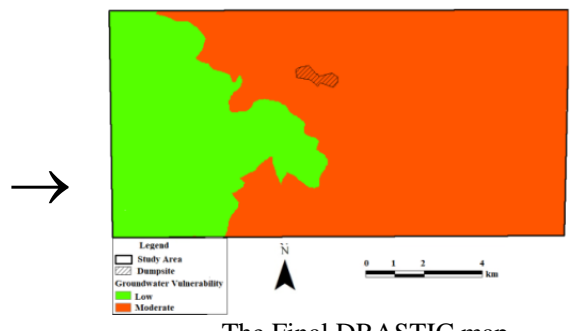

The Final DRASTIC map

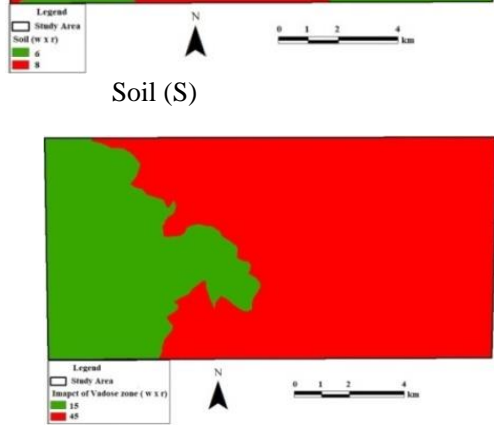

Impact of Vadose Zone (I)

Fig. 3. DRASTIC index parameters and final DRATIC map.

TABLE IV: THE SWSI PARAMETERS FOR THE STUDY AREA (MODIFIED FROM [33])

\begin{tabular}{|c|c|c|c|c|c|c|c|c|c|}
\hline SWSi parameters & Class & Weight & Rating & $\mathbf{w} \times \mathbf{r}$ & SWSi parameters & Class & Weight & Rating & $\mathbf{w} \times \mathbf{r}$ \\
\hline \multirow{2}{*}{$\begin{array}{c}\text { Gradient Slope (GS) } \\
(\%)\end{array}$} & $>20$ & \multirow{2}{*}{6} & 5 & 30 & \multirow{2}{*}{ Soil Clay (SC) (\%) } & $>25-\leq 30$ & \multirow{2}{*}{4} & 4 & 16 \\
\hline & $\leq 2$ & & 1 & 6 & & $>20-\leq 25$ & & 3 & 12 \\
\hline \multirow{5}{*}{$\begin{array}{l}\text { Distance to Wadi } \\
\text { (DW) (m) }\end{array}$} & $\leq 50$ & \multirow{5}{*}{5} & 5 & 25 & \multirow{5}{*}{$\begin{array}{l}\text { Distance to } \\
\text { Agricultural lands } \\
\text { (DA) (m) }\end{array}$} & $\leq 500$ & \multirow{5}{*}{3} & 5 & 15 \\
\hline & $>50-\leq 100$ & & 4 & 20 & & $>500-\leq 1000$ & & 4 & 12 \\
\hline & $>100-\leq 200$ & & 3 & 15 & & $>1000-\leq 2000$ & & 3 & 9 \\
\hline & $>200-\leq 500$ & & 2 & 10 & & $>2000-\leq 5000$ & & 2 & 6 \\
\hline & $>500$ & & 1 & 5 & & $>5000$ & & 1 & 3 \\
\hline \multirow{5}{*}{$\begin{array}{l}\text { Distance to Urban } \\
\text { Areas (DU) (m) }\end{array}$} & $\leq 500$ & \multirow{5}{*}{2} & 5 & 10 & \multirow{5}{*}{$\begin{array}{l}\text { Distance to Roads } \\
\text { (DR) (m) }\end{array}$} & $\leq 500$ & \multirow{5}{*}{1} & 5 & 5 \\
\hline & $>500-\leq 1000$ & & 4 & 8 & & $>500-\leq 1000$ & & 4 & 4 \\
\hline & $>1000-\leq 2000$ & & 3 & 6 & & $>1000-\leq 2000$ & & 3 & 3 \\
\hline & $>2000-\leq 5000$ & & 2 & 4 & & $>2000-\leq 5000$ & & 2 & 2 \\
\hline & $>5000$ & & 1 & 2 & & $>5000$ & & 1 & 1 \\
\hline
\end{tabular}

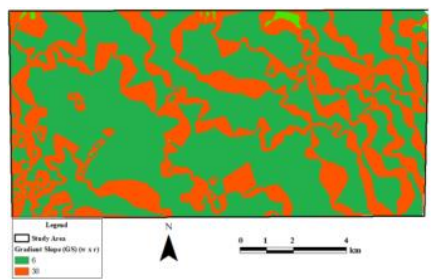

Gradient Slope (GS)

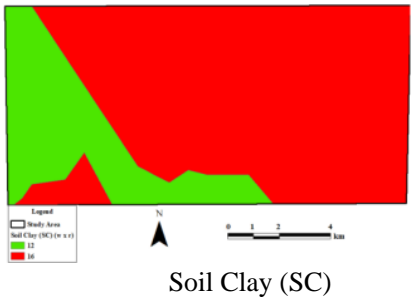

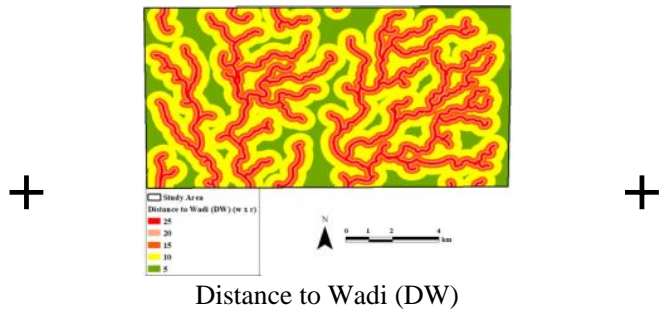

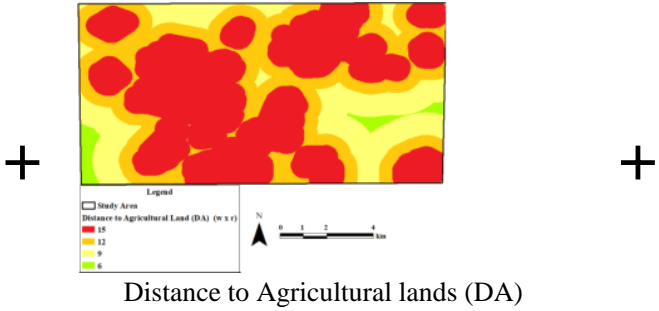



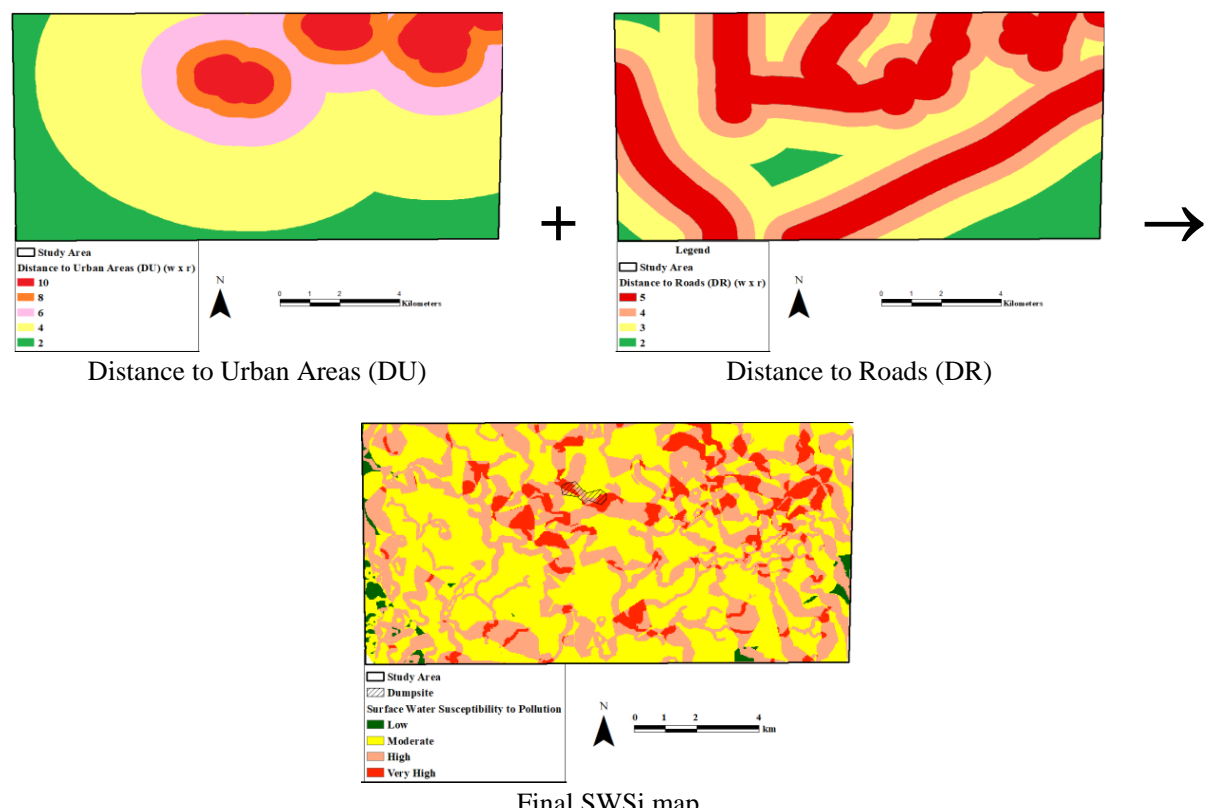

Fig. 4. SWSi index parameters and the Final SWSi map.

\section{CONCLUSION AND RECOMMENDATIONS}

Mafraq dumpsite is located within the Mafraq governorate and receives various types of municipal solid waste from Mafraq City, Za'atari Refugee Camp and several towns and villages in the area. In this research, a novel approach of using two indices to examine the groundwater vulnerability to contamination and surface water susceptibility to pollution for the area surrounding the Mafraq dumpsite. The DRASTIC index was used to investigate the groundwater vulnerability to contamination in the surrounding area of the dumpsite. It was found that the dumpsite is located within a moderate groundwater vulnerability to contamination zone. This means that the dumpsite might affect the groundwater quality in the area as indicated by previous studies. The Surface Water Susceptibility to Pollution Index (SWSi) was used to examine whether Mafraq dumpsite would affect the surface water quality in the area or not. It was found that the dumpsite is located within an area of high and very surface susceptibility to pollution

Based on this research findings, it is recommended that in order to improve the management of the Mafraq dumpsite and reduce adverse complications, the following must be considered;

- The local authorities must control the type and amount of waste placed in the dumpsite. High toxic materials should be separated and removed for specialized disposal. Waste must be reduced and recycled before entering the dumpsite.

- Artificial lining systems must be applied at the dumpsite to ensure that leachates from the dumpsite do not reach groundwater.

- Establishing a groundwater quality monitoring system. Also, water sampling and analysis of runoff from Wadis close to the dumpsite during winter season and at various distances.

\section{ACKNOWLEDGMENT}

This research was carried out by Rida Al-Adamat while on sabbatical leave from $\mathrm{Al}$ al-Bayt University for the academic year (2017/2018). The author would like to show appreciation and give thanks to $\mathrm{Al}$ al-Bayt University president, the Dean of Institute of Earth and Environmental Sciences. The author also acknowledges the help and support of the Dean and staff of The Scientific Research Deanship at Al Al-Bayt University. Critical and constructive review of the manuscript by the reviewers is greatly treasured.

\section{REFERENCES}

[1] B. Potter et al., "Jordan: Urban expansion, social polarisation and contemporary urban planning issues," Habitat. Int., vol. 33, pp. 81-92, 2009.

[2] R. Octavio, "Factors affecting agriculture water use in the Mafraq basin of Jordan: Quantitative analyses and policy implications," New Mexico State University and Badia Research and Development Center, 2008.

[3] M. Aljaradin and K. M. Persson, "Current situation of municipal solid waste landfill in Jordan," Waste Management Journal, vol. 31, pp. 1897-1900, 2011

[4] SWEEP, "Country profile on solid waste management situation," The Regional Solid Waste Exchange Information and Expertise Network in Mashreq and Maghreb Countries, 2010.

[5] M. Chopra et al., "US-Jordan municipal solid waste management collaborative research," The National Science Foundation, University of Central Florida, Arlington, USA, 2001.

[6] A. A. R. Taylor, Waste Disposal and Landfill: Potential Hazards and Information Needs, 2003.

[7] P. Beigl and S. Lebersorger, "Forecasting municipal solid waste generation for urban and rural regions," XII International Waste Management and Landfill Symposium Sardinia, Italy, 2009.

[8] A. Alistair, "Containment landfills: the myth of sustainability," Engineering Geology, vol. 60, pp. 3-19, 2001.

[9] UNDP (United Nation Development Programme), "Solid waste value chain analysis Irbid and Mafraq Jordan,” 2015.

[10] M. L. Hossain, S. R. Das, and M. K. Hossain, "Impact of landfill leachate on surface and ground water quality," Journal of Environmental Science and Technology, vol. 7, no. 6, pp. 337-346, 2014.

[11] O. Al-Meshan, "Location Criteria for domestic and Hazardous Waste disposal to landfill in the Jordanian Badia using GIS," Ph.D. Thesis, Coventry University, UK, 2005.

[12] N. AlAnsari et al., "Solid waste management and disposal in Mafraq city," Hydrogeologie und Umwelt, vol. 33, pp. 1-21, 2005.

[13] M. Aljaradin and K. M. Persson, "Design of sanitary landfills in Jordan for sustainable solid waste management," Journal of Applied Sciences Research, vol. 6, pp. 1880-1884, 2010.

[14] Z. Tadros, "Site selection and management of solid wastes disposal site. case study," Ghabawi landfill-Jordan, Eleventh International Waste 
Management and Landfill, S. Marhgerita di Pula - Cagliari, Sardinia, Italy, 2007.

[15] K. S. Murray and D. T. Rogers, "Groundwater vulnerability, brownfield redevelopment and land use planning," Journal of Environmental Planning and Management, vol. 42, pp. 801-810, 1999.

[16] L. Aller et al., "DRASTIC-A standardized system to evaluate groundwater pollution potential using hydrogeologic setting," Journal of the Geological Society of India, vol. 29, pp. 23-37, 1987.

[17] B. M. Evans and W. L. Myers, "A GIS-based approach to evaluating regional groundwater pollution potential with DRASTIC," Journal of Soil and Water Conservation, vol. 45, pp. 242-245, 1990.

[18] S. L. Stark et al., "Using GIS to investigate septic system sites and nitrate pollution potential," Journal of Environmental Health, vol. 61 , pp. 15-20, 1999.

[19] T. G. Fritch et al., "An aquifer vulnerability assessment of the Paluxy Aquifer, Central Texas, USA, using GIS and a modified DRASTIC approach," Environmental Management, vol. 25, pp. 337-345, 2000.

[20] R. A. Al-Adamat et al., "Groundwater vulnerability and risk mapping for the Basaltic aquifer of the Azraq basin of Jordan using GIS, Remote sensing and DRASTIC," Applied Geography, vol. 23, no. 4, pp 303-324, 2003.

[21] M. Al-Farajat et al., "Geo-structural analysis accompanied by GIS vulnerability mapping validated by hydro-chemical modeling in determining spatial expansion of landfills: Case study from Jordan," Jordan Journal of Civil Engineering, vol. 10, no. 3, pp. 367-389, 2016.

[22] T. Abdullah et al., "Groundwater vulnerability using DRASTIC and COP models: Case study of Halabja Saidsadiq Basin, Iraq," Engineering, vol. 8, pp. 741-760, 2016

[23] S. Foster, "Fundamental concepts in aquifer vulnerability, pollution risk and protection strategy: International conference, 1987, Noordwijk Aan Zee," the Netherlands Vulnerability of Soil and Groundwater to Pollutants. Netherlands Organization for Applied Scientific Research, The Hague, pp. 69-86, 1987.

[24] C. Neukum and H. Hötzl, "Standardization of vulnerability maps," Environmental Geology, vol. 51, pp. 689-694, 2007.

[25] A. Alvarado et al., "Multi-criteria decision analysis and GIS approach for prioritization of drinking water utilities protection based on their vulnerability to contamination," Water Resources Management, vol. 30 pp. 1549-1566, 2016

[26] N. Doerfliger et al., "Water vulnerability assessment in Karst environments: A new method of defining protection areas using a multi attribute approach and GIS tools (EPIK Method)," Environmental Geology, vol. 39, pp. 165-176, 1999.

[27] J. Vias et al., "A comparative study of four schemes for groundwater vulnerability mapping in a diffuse flow carbonate aquifer under mediterranean climatic conditions," Environmental Geology, vol. 47, pp. 586-595, 2005.

[28] I. Hamdan et al., "Groundwater vulnerability assessment for the karst aquifer of Tanour and Rasoun springs catchment area (NW-Jordan) using COP and EPIK intrinsic methods," Environmental Earth Sciences, vol. 75, no. 23, p. 1474, 2016.

[29] A. Corniello et al., "Aquifer pollution vulnerability in the Sorrento Peninsula, Southern Italy evaluated by SINTACS method," Geofisica Internacional-Mexico, vol. 43, pp. 575-581, 2004.

[30] S. Kumari et al., "Groundwater vulnerability assessment using SINTACS model and GIS in Raipur and Naya Raipur, Chhattisgarh, India," Indian Journal of Science and Technology, vol. 9, pp. 1-6, 2016.

[31] A. M. Al-Shatnawi et al., "Vulnerability mapping of groundwater aquifer Using SINTACS in Wadi Al-Waleh Catchment, Jordan," Arabian Journal of Geosciences, vol. 9, p. 67, 2016.

[32] N. Goldscheider et al., "The PI method - A GIS based approach to mapping groundwater vulnerability with special consideration of Karst aquifers," Zeitschrift für Angewandte Geologie, vol. 46, pp. 157-166, 2000.

[33] R. Al-Adamat and A. A. R. Al-Shabeeb, "A simplified method for the assessment of groundwater vulnerability to contamination," Journal of Water Resource and Protection, vol. 9, no. 03, pp. 305-321, 2017.

[34] R. Al-Adamat, "Modelling surface water susceptibility to pollution using GIS," Journal of Geographic Information System, vol. 9, no. 03, pp. 293-308, 2017.
[35] C. Diamantino et al., "Methodologies for pollution risk assessment of water resources systems," IAHS Publication, vol. 310, 298-306, 2007.

[36] J. L. Eimers et al., "Methods of Rating unsaturated zone and watershed characteristics of public water supplies in North Carolina. U.S. geological survey, water-resources investigations, Raleigh, North Carolina, Report 99-4283.," 2000.

[37] D. Gallegos et al., "State of New Mexico Source water assessment and protection program," Appendix E: WRASTIC Index: WATERSHED VULNERABILITY ESTIMATION USING WRASTIC), 2000.

[38] UMD (the University of Minnesota-Duluth), "Cass County-Ten mile lake association water resource management tools," 2003.

[39] T. Harum et al., "Water resources, vulnerability assessment and quality of water in cachoeira catchement," Newsletter ECOMAN, No 3-Decision Support System for Sustainable ECOsystem MANagement in Atlantic Rain Forest Rural Areas, 20104

[40] A. Al-Harahsheh et al., "Potential impacts on surface water quality from the utilization of oil shale at Lajjoun Area/Southern Jordan using geographic information systems and leachability tests," Energy Sources, Part A: Recovery, Utilization, and Environmental Effects, vol 32, pp. 1763-1776, 2010 .

[41] A. A. R. R. Al-Shabeeb, "Investigating the impacts of king Hussein Bin Talal development area (KHBTDA) on water resources using (GIS)," MSC dissertation, Al al-Bayt University, Jordan, 2010.

[42] J. Ritter and P. Eng, "Soil erosion-causes and effects, Ontario Ministry of Agriculture and Rural Affairs, 12-105," 2012.

[43] EPA (Environmental Protection Agency), Protecting Water Quality from Agricultural Runoff, EPA 841-F-05-001, 2005.

[44] M. K. Riley, "The effects of urbanization on water quality: A biological assessment of three bay area watersheds using benthic macroinvertebrates as biological indicators," Water Quality and Urbanization, pp. 1-20. 2008.

[45] M. Bruen et al., "Impact assessment of highway drainage on surface water quality," Environmental Protection Agency, Wexford. 2006.

[46] R. Al-Adamat et al., "Predicted soil organic carbon stocks and changes in Jordan between 2000 and 2030 made using the GEFSOC modelling system," Agriculture, Ecosystems \& Environment, vol. 122, no. 1, pp. $35-45,2007$.

[47] N. H. Batjes et al., "Soil data derived from SOTER for studies of carbon stocks and change in Jordan (version 1.0) (No. 2003/04)," ISRIC-World Soil Information, 2003

[48] R. Al-Adamat et al., "An examination of agricultural land use change in the north-eastern Badia, Jordan using remote sensing and GIS," International Journal of Environmental Studies, vol. 61, no. 3, pp. 337-350. 2004

[49] R. Al-Adamat, "The use of GIS and Google earth for preliminary site selection of groundwater recharge in the Azraq Oasis Area-Jordan," Journal of Water Resource and Protection, vol. 4, no. 6, pp. 395-399, 2012.

[50] M. Obeidat et al., "Analysis and evaluation of nitrate levels in groundwater at AlHashimiya area, Jordan, "Environmental Monitoring Assessment, vol. 135, pp. 475-486, 2007.

[51] N. Schoeffler et al., "Groundwater quality in the surroundings of Mafraq landfill, Jordan," Vatten: tidskrift för vattenvård/Journal of Water Management and research, vol. 69, 2012.

[52] WHO (World Health Organization), Guidelines for Drinking-Water Quality, Switzerland, 2008

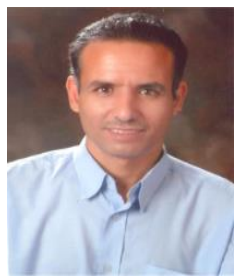

Rida Al-Adamat was born in Mafraq Governorate, Jordan on the $3^{\text {rd }}$ of August 1969. He received his BSc in electronics engineering from Arab Academy for Science and Technology and Maritime Transport, Egypt in 1993, his MSc in geographical information for Development from Durham University, UK in 1996 and his $\mathrm{PhD}$ in the use of geographical information systems and remote sensing to investigate groundwater quality in the Azraq Basin/ Jordan from Coventry University, UK in 2003. He is currently a full professor in the field of GIS and remote sensing at Al al-Bayt University. His current research interests include environmental modelling, land use planning and Water resources management. 